
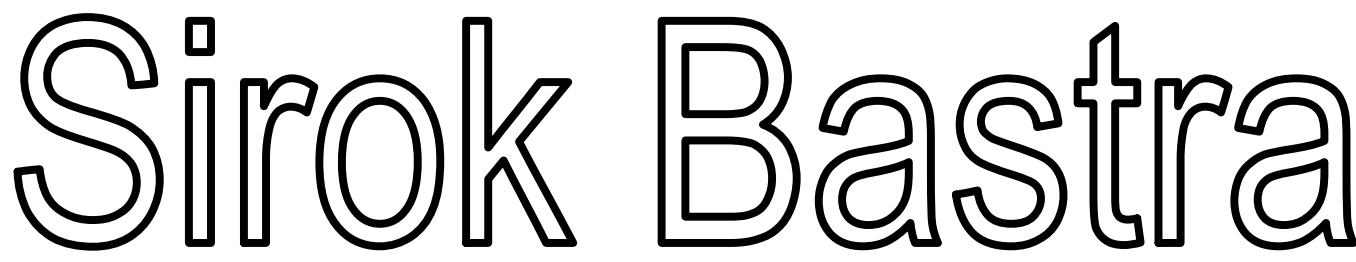

J URNAL ILMIAH KEBAHASAAN DAN KESASTRAAN

\begin{tabular}{|c|c|c|c|c|c|}
\hline $\begin{array}{c}\text { Sirok Bastra } \\
\text { Jurnal Kebahasaan dan } \\
\text { Kesastraan }\end{array}$ & Volume 5 & Nomor 2 & $\begin{array}{c}\text { Hlm. } \\
101-196\end{array}$ & $\begin{array}{c}\text { Pangkalpinang, } \\
\text { Desember } \\
2017\end{array}$ & $\begin{array}{c}\text { ISSN } \\
2354-7200\end{array}$ \\
\hline
\end{tabular}

KANTOR BAHASA KEPULAUAN BANGKA BELITUNG 


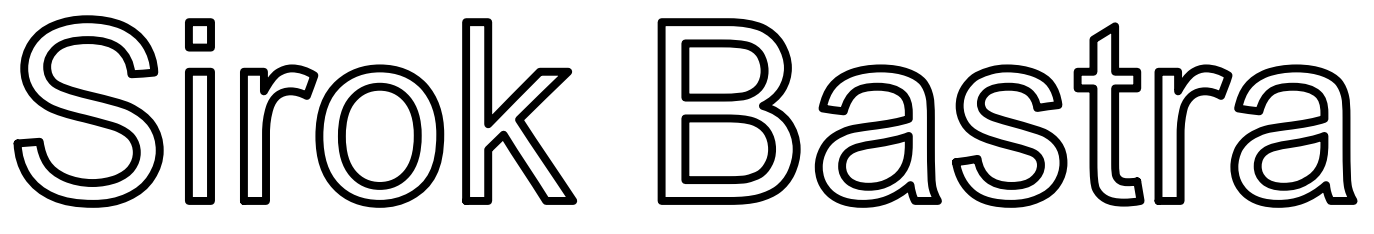

\section{J URNAL ILMIAH KEBAHASAAN DAN KESASTRAAN}

Jurnal ini merupakan wadah informasi kebahasan, kesastraan, dan pengajarannya yang memuat hasil penelitian, studi kepustakaan, dan tulisan ilmiah bidang kebahasan dan kesastraan serta pengajarannya. Sirok Bastra terbit dua kali setahun, yakni Juni dan Desember, serta terbit sejak Juni 2013.

\section{Penanggung Jawab}

Kepala Kantor Bahasa Kepulauan Bangka Belitung

Drs. Hidayatul Astar, M.Hum.

\section{Mitra Bestari}

Prof. Dr. Agus Nuryatin, M.Hum. (Bidang Sastra dan Pengajarannya)

Prof. Amrin Saragih, Ph.D., M.A. (Bidang Bahasa dan Pengajarannya)

Dr. Felicia Nuradi Utorodewo, M.Hum. (Bidang Bahasa dan Pengajarannya)

Dr. Pujiharto, M.Hum. (Bidang Sastra dan Pengajarannya)

\section{Pemimpin Redaksi}

Rahmat Muhidin, S.S.

\section{Penyunting}

Dr. Asyraf Suryadin, M.Pd.

Prima Hariyanto, S.Hum.

Sarman, S.Pd.

\section{Perancang Sampul}

Feri Pristiawan, S.S.

\section{Pengatak}

Dewi Septi Kurniawati, S.Kom.

\section{Kesekretariatan \\ Ria Anggraini, S.E. Juliati, S.E.}

\section{Alamat Redaksi dan Penerbit}

Kantor Bahasa Kepulauan Bangka Belitung

Jalan Letkol Saleh Ode No. 412, Kota Pangkalpinang, Prov. Kepulauan Bangka Belitung Telepon (0717) 438455, Faksimile(0717)9103317, Pos-el: sirokbastra@gmail.com, sirokbastra@kemdikbud.go.id

Pemuatan suatu tulisan dalam jurnal ini tidak berarti redaksi menyetujui isi tulisan tersebut. Isi tulisan menjadi tanggung jawab penulis. Tulisan telah ditinjau dan diulas oleh mitra bestari. Setiap karangan dalam jurnal ini dapat diperbanyak setelah mendapat izin tertulis dari penulis, redaksi, dan penerbit. 


\section{PENGANTAR}

Puji syukur ke hadirat Pemilik dan Pencipta semesta ini yang memiliki kuasa atas diri-Nya sendiri. Dialah Tuhan Yang Maha Esa yang telah memberikan rahmat dan hidayah-Nya sehingga Volume 5 Nomor 2 Jurnal Sirok Bastra Tahun 2017 dapat terbit tepat pada waktunya.

Pada edisi ini dimuat sepuluh tulisan, yakni lima tulisan kebahasaan, empat tulisan kesastraan, dan satu tulisan pengajaran sastra.

Dalam penelitiannya, Hotnida Novita Sary menganalisis iklan komersial Meikarta yang telah membuat perusahaan tersebut berhasil mencatatkan penjualan yang fantastis. Penelitian yang dilakukannya menggunakan pisau bedah analisis wacana kritis Fairclough (1989). Iklan Meikarta membandingkan kesuperioritasan mereka dibandingkan kota metropolitan lain, seperti Jakarta. Meikarta juga menanamkan ideologi bagi masyarakat kota besar bahwa kota metropolitan saat ini sudah tidak aman, kotor, dan macet.

Dalam makalahnya, Hidayatul Astar mengkaji realisasi konsep bahasa Indonesia ke dalam bahasa Rejang. Menurutnya, masyarakat Rejang tidak memiliki konsep (kata atau istilah) yang cukup untuk mewakili pikiran dan perasaan tertentu ketika berkomunikasi, terutama yang terkait dengan konsep kehidupan modern atau yang sesuai dengan perkembangan zaman. Karena itu, bahasa Rejang perlu memungut atau mengambil dari bahasa lain, khususnya dari bahasa Indonesia. Realisasi bentuk konsep yang ditemukan adalah realisasi tanpa perubahan dan realisasi dengan perubahan. Berdasarkan data, realisasi perubahan dalam sebuah konsep dapat satu kali atau lebih. Realisasi perubahan itu berupa penghilangan, penggantian, dan penambahan bunyi vokal atau konsonan tertentu pada posisi tertentu. Terjadinya perubahan realisasi bunyi bahasa Indonsia ke dalam bahasa Rejang disebabkan oleh keinginan penutur bahasa Rejang dan adaptasi terhadap bunyi yang sudah ada.

Dalam kajiannya, Mardi Nugroho membahas pembentukan kata dalam bahasa Talondo di Sulawesi Barat. Hasil analisis data menunjukkan bahwa ada tiga macam cara pembentukan kata dalam bahasa Talondo, yaitu afiksasi, reduplikasi, dan pemajemukan. Pembentukan kata dengan afiksasi terdiri atas pembentukan kata dengan prefiksasi, konfiksasi, infiksasi, dan sufiksasi. Pembentukan kata dengan reduplikasi terdiri atas reduplikasi murni, reduplikasi sebagian, dan reduplikasi yang berkombinasi dengan afiksasi.

Dalam kajiannya, Muhammad Fadely membahas makna dan bentuk pemakaian eufemisme dan disfemisme dalam feature karya Ruslan Ismail Mage yang bermanfaat bagi pengajaran bahasa Indonesia dan pengembangan bahasa di media massa cetak. Hasil analisis menunjukkan bahwa pemakaian eufemisme lebih banyak daripada pemakaian disfemisme. Berdasarkan simpulan tersebut, peneliti menyarankan bahwa dalam menyampaikan suatu informasi kepada khalayak umum hindari tulisan-tulisan yang dapat mengaburkan dan tidak terus terang demi maksud-maksud tertentu.

Dalam kajiannya, Asri Soraya Afsari membahas karakteristik bahasa yang digunakan dalam iklan komersial ponsel yang berada di Kota Bandung. Hasil penelitian menunjukkan bahwa bentuk dan fungsi bahasa yang digunakan dalam iklan ponsel di Kota Bandung berupa penulisan huruf kapital secara keseluruhan dan penulisan huruf kapital pada awal kata. Bahasa iklan ponsel memiliki fungsi informatif dan konatif (persuatif).

Dalam tulisannya, Erwin Wibowo mendeskripsikan makna semiotik budaya Lampung yang ada di dalam antologi Kitab Cerpen Perempuan di Rumah Panggung. Hasil penelitian mengungkapkan ikon, indeks, dan simbol budaya Lampung melalui pendekatan semiotik yang dipakai dalam Kitab Cerpen Perempuan di Rumah Panggung karya Isbedy Stiawan ZS dan memberi deskripsi tentang ikon, indeks, dan simbol tesebut.

Dalam penelitiannya, Prima Hariyanto membahas penokohan dalam Kitab Omong Kosong yang mengambil cerita epos Ramayana. Dalam novel ini, pengarang mengubah pola cerita. Tokoh sentral dalam cerita ini bukan lagi Rama dan Sinta, tetapi Maneka dan Satya. Ceritanya bukan lagi kisah cinta Rama dan Sinta, tetapi kisah perjalanan Maneka dan Satya dalam mencari Kitab Omong Kosong ciptaan Hanoman. Tokoh Rama tidak lagi diceritakan sebagai kesatria yang baik, tetapi sebagai raja yang membawa bencana bagi rakyat di muka bumi.

Dalam kajiannya, Dian Anggraini mengkaji intertekstual lima puisi Indonesia yang berisi tentang sosok wanita yang disebut ibu, yaitu "Ibu Dehulu" (Amir Hamzah), "Ibu” (Chairil Anwar), "Sajak Ibu” (Wiji Thukul), 
"Bunda Air Mata" (Emha Ainun Najib"), dan "Ibu” (K.H. Mustofa Bisri). Hasil telaah itu membuktikan bahwa kelima puisi tersebut merupakan mosaik, kutipan-kutipan, penyerapan, dan perspektif yang beragam terhadap sosok ibu. Setiap penyair mengungkapkan sisi ibu dari pandangan yang berbeda.

Dalam kajiannya, Yuliadi M.R. membahas makna ground dalam cerpen "Uak dan Burung Gagak" dengan pendekatan objektif melalui teori semiotik Pierce. Berdasarkan kajian, terungkap bahwa makna ground dalam cerpen Uak dan Burung Gagak, yaitu ground qualisign berupa warna hitam, sinsign berupa suara koakkoak, dan legisign berupa perilaku mengitari rumah.

Dalam tulisannya, Abdul Azis dan Hajrah membahas dongeng sebagai bahan pembelajaran di sekolah dasar. Data penelitian ini adalah dongeng Cerita Si Jingkiriq, I Kukang, Nenek Pakande, La Dana dan Kerbaunya, dan Puang Tedong. Hasil analisis data dan temuan menunjukkan bahwa rata-rata penilaian responden untuk dongeng sebesar 3,75 (kategori layak dijadikan bahan ajar). Bahan ajar yang dapat digunakan untuk tingkat SD adalah dongeng yang isinya sesuai dengan karakteristik, pengalaman, dan kebutuhan siswa.

Kami mengucapkan terima kasih kepada para penulis yang telah bersedia menerbitkan karya mereka pada edisi ini. Para penulis merupakan peneliti, pakar, dosen, dan mahasiswa dari berbagai perguruan tinggi dan instansi. Terima kasih juga kami sampaikan kepada para mitra bestari kami yang telah memberi ulasan terhadap tulisan-tulisan yang masuk ke redaksi.

Demi memenuhi keberagaman isi dan penulis, Sirok Bastra membuka kesempatan bagi para peneliti dan penulis menyampaikan hasil penelitian dan pemikiran mutakhir dalam bidang kebahasaan, kesastraan, dan pengajarannya. 


\section{UCAPAN TERIMA KASIH UNTUK MITRA BESTARI}

Redaksi Sirok Bastra mengucapkan terima kasih kepada para mitra bestari yang telah meninjau, menimbang, dan mengulas makalah-makalah yang diterbitkan dalam Sirok Bastra Volume 5 Nomor 2, edisi Desember 2017, yakni

Prof. Dr. Agus Nuryatin, M.Hum.

Bidang Sastra dan Pengajarannya

Universitas Negeri Semarang

Semarang, Jawa Tengah

Prof. Amrin Saragih, Ph.D., M.A.

Bidang Bahasa dan Pengajarannya

Universitas Negeri Medan

Medan, Sumatra Utara

Dr. Felicia Nuradi Utorodewo, M.Hum.

Bidang Bahasa dan Pengajarannya

Universitas Indonesia

Depok, Jawa Barat

\section{Dr. Pujiharto, M.Hum.}

Bidang Sastra dan Pengajarannya

Universitas Gadjah Mada

Yogyakarta, Daerah Istimewa Yogyakarta 


\section{DAFTAR ISI}

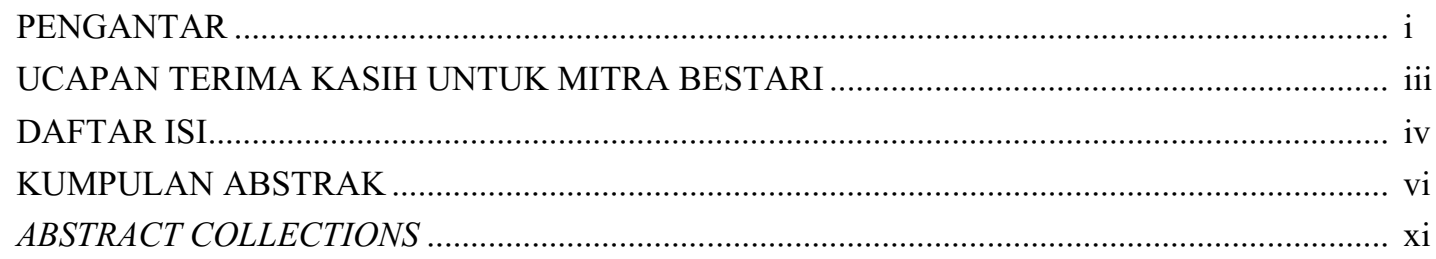

ANALISIS WACANA KRITIS IKLAN KOMERSIAL MEIKARTA

(Critical Discourse Analysis of Meikarta Commercial Advertising)

Hotnida Novita Sary $101-111$

REALISASI KONSEP BAHASA INDONESIA DALAM BAHASA REJANG

(Realization of Indonesian Concept Into Rejang Language)

Hidayatul Astar. $113-121$

PEMBENTUKAN KATA DALAM BAHASA TALONDO

(The Word Formation in Talondo Language)

Mardi Nugroho $123-129$

EUFEMISME DAN DISFEMISME PADA FEATURE-FEATURE KARYA RUSLAN ISMAIL MAGE

(Euphemism and Disphemism in The Features by Ruslan Ismail Mage)

Muhammad Fadely $131-139$

KARAKTERISTIK PENGGUNAAN BAHASA DALAM IKLAN PONSEL DI KOTA BANDUNG

(The Characteristic of Language Usage on Mobile Phone Advertisement in Bandung) Asri Soraya Afsari $141-151$

SIMBOL BUDAYA LAMPUNG DALAM KITAB CERPEN PEREMPUAN DI RUMAH PANGGUNG KARYA ISBEDY STIAWAN Z.S.: KAJIAN SEMIOTIKA

(Lampung Cultural Symbols in Kitab Cerpen Perempuan di Rumah Panggung by Isbedy Stiawan Z.S.: a Semiotic Analysis)

Erwin Wibowo $153-161$

PENOKOHAN DALAM KITAB OMONG KOSONG KARYA SENO GUMIRA AJIDARMA (Characterization in Kitab Omong Kosong by Seno Gumira Ajidarma)

Prima Hariyanto $163-169$

WANITA ISTIMEWA: KAJIAN INTERTEKSTUAL TERHADAP PUISI-PUISI TENTANG IBU

(Special Woman: Intertextual Study of Poems About Mother) 
BURUNG GAGAK SEBUAH TANDA: MAKNA GROUND DALAM CERPEN UAK DAN BURUNG GAGAK

(Brids Crow A Sign: Ground Meaning in Uak and Burung Gagak Short Story)

Yuliadi M.R.

DONGENG SEBAGAI BAHAN PEMBELAJARAN BAHASA INDONESIA DI SEKOLAH

DASAR

(Folktale as Indonesian Language Learning Material in Elementary School)

Abdul Azis dan Hajrah

$191-196$ 


\title{
REALISASI KONSEP BAHASA INDONESIA DALAM BAHASA REJANG
}

\section{Realization of Indonesian Concept Into Rejang Language}

\author{
Hidayatul Astar
}

\author{
Kantor Bahasa Kepulauan Bangka Belitung \\ Jalan Letkol Saleh Ode 412, Pangkalpinang \\ Pos-el: hidayatul.astar@yahoo.co.id
}

(diterima 11 Agustus 2017, disetujui 19 Oktober 2017, revisi terakhir 5 Desember 2017)

\begin{abstract}
Abstrak
Artikel ini merupakan hasil kajian terhadap realisasi konsep bahasa Indonesia ke dalam bahasa Rejang. Kenyataan menunjukkan bahwa masyarakat Rejang tidak memiliki konsep (kata atau istilah) yang cukup untuk mewakili pikiran dan perasaan tertentu ketika berkomunikasi, terutama yang terkait dengan konsep kehidupan modern atau yang sesuai dengan perkembangan zaman. Karena itu, bahasa Rejang perlu memungut atau mengambil dari bahasa lain, khususnya dari bahasa Indonesia. Ada dua realisasi bentuk konsep yang terjadi, yaitu realisasi tanpa perubahan dan realisasi dengan perubahan. Berdasarkan data, realisasi perubahan dalam sebuah konsep dapat satu kali atau lebih. Realisasi perubahan itu berupa penghilangan, penggantian, dan penambahan bunyi vokal atau konsonan tertentu pada posisi tertentu. Penghilangan terbanyak terdapat pada konsonan $[\mathrm{r}]$ dan penggantian terbanyak dari konsonan [h] menjadi [k]. Terjadinya perubahan realisasi bunyi bahasa Indonsia ke dalam bahasa Rejang disebabkan oleh, antara lain, keinginan penutur bahasa Rejang dan adaptasi terhadap bunyi yang sudah ada.
\end{abstract}

Kata kunci: konsep, bahasa Rejang, bahasa Indonesia, perubahan

\begin{abstract}
This article is the result of a study about realization of Indonesian concept into Rejang language. The fact shows that Rejang society does not have enough concepts (words or terms) to represent their thoughts and feelings when they are communicate to each other, especially the concept of modern life. Rejang language needs to borrow from other languages, for example, Indonesian language. There are two realizations of concepts, realization without change and realization with change. Based on data, the realization of a change in a concept can be one or more. The realization of the change is elimination, substitution, and addition of certain vowels or consonants at certain positions. The elimination of consonant $[\mathrm{r}]$ are very often and the largest replacement of the consonant [h] into [k]. The change in the realization of Indonesian language into Rejang language is caused by the desire of speakers of Rejang language and adaptation to existing sounds.
\end{abstract}

Keywords: concept, Rejang language, Indonesian language, change

\section{PENDAHULUAN}

\subsection{Latar Belakang}

Menurut Juwono (1998:18) kebinekaan bahasa daerah, memberikan sumbangan yang berarti terhadap bahasa Indonesia, yaitu dalam hal pemerkayaan kosa kata. Sebaliknya, bahasa Indonesia pun memberikan sumbangan yang cukup terhadap bahasa daerah. Namun, ada kecenderungan yang tampak di tengah masyarakat pada saat ini, terutama mereka yang bermukim di perkotaan dan kalangan generasi muda atau terpelajar. Mereka lebih tertarik menggunakan bahasa Indonesia atau bahasa asing (khususnya bahasa Inggris) dalam kehidupan sehari-hari daripada bahasa ibu/bahasa daerahnya. Kecenderungan itu merupakan ancaman bagi eksistensi bahasa daerah, termasuk bahasa Rejang.

Bahasa Rejang merupakan salah satu bahasa daerah yang terdapat di Provinsi Bengkulu (Tim Pemetaan Bahasa, 2008: 32). Bahasa ini juga sudah 
diidentifikasi sebagai bahasa sendiri oleh SIL (2006). Bahasa Rejang begitu berbeda dengan bahasa lain di wilayah Provinsi Bengkulu. Dalam sejarah memang disebutkan bahwa bahasa Rejang merupakan bahasa suku Rejang, salah satu suku tertua di Sumatera.Wilayah pakai bahasa itu berada di Kabupaten Rejang Lebong, Kabupaten Lebong, Kabupaten Bengkulu Utara, Kabupaten Kepahiang, dan Kabupaten Bengkulu Tengah. Sebuah wilayah pakai yang cukup luas.

Dalam perkembangannya bahasa Rejang tidak terlepas dari pengaruh bahasa yang digunakan oleh masyarakat pada saat ini, khususnya bahasa nasional, bahasa Indonesia. Pengaruh itu terlihat ketika dicermati pada konsep tertentu penutur Rejang menggunakan bahasa Indonesia karena memang tidak ada dalam konsep berpikir masyarakat Rejang.

\subsection{Masalah}

Sehubungan dengan itu, dalam artikel ini dikemukakan masalah berikut.

a. Konsep hidup apa saja yang diserap bahasa Rejang dari bahasa Indonesia

b. Bagaimana Realisasi bentuk bahasa Indonesia ke dalam bahasa Rejang.

c. Bagaimana perubahan realisasi bahasa Indonesia ke dalam bahasa Rejang.

\subsection{Tujuan}

Tujuan kajian ini adalah untuk mengidentifikasi dan mengetahui konsep hidup apa saja yang diserap oleh bahasa Rejang dari bahasa Indonesia dan bagaimana bentuk realisasinya. Selain itu, kajian ini bertujuan untuk mengetahui perubahan realisasi konsep dalam bahasa Indonesia ke dalam bahasa Rejang.

\subsection{Manfaat}

Kajian ini bermanfaat bagi penambahan kajian linguistik, khususnya dalam kaijian perbandingan bahasa (linguistik bandingan). Data kajian ini dapat digunakan oleh para peneliti atau pemerhati bahasa Rejang sebagai acuan untuk mengetahui konsep yang diserap dan bagaiaman realisasinya dari bahasa Indonesia ke dalam bahasa Rejang.

\section{TEORI DAN METODE}

Perkembangan sebuah bahasa tidak terlepas dari perkembangan masyarakatnya. Sebuah bahasa akan tetap hidup jika masyarakat penuturnya menginginkan. Sebaliknya, sebuah bahasa akan punah jika penuturnya tidak menginginkan atau tidak menggunakannnya lagi karena dianggap ketinggalan zaman atau malu menggunakannya.

Perubahan yang terjadi dalam subuah bahasa kadang-kadang tidak terasa setiap waktu (Robins 1989/1992:417). Perubahan itu dapat berupa perubahan secara fonologis, morfologis, sintaksis, dan semantik. Sehungan dengan itu, dalam kajian ini dimanfaatkan kerangka berpikir yang terkait dengan perubahan bahasa itu, khususnya perubahan bunyi. Beberapa prinsip perubahan bunyi atau bentuk telah dikemukan, antara lain, oleh Hock (1986:61--117), Crowly (1987:24--47), dan (Mahsun 1995:30).

Ada beberapa jenis perubahan bunyi yang telah dikemukan oleh para linguis tersebut, yaitu asimilasi, disimilasi, metatesis, kontraksi, aferesis, sinkope, apokope, protesis, epentesis, dan paragog akan menjadi acuan analisis data. Berdasarkan pengamatan terhadap data, tidak semua perubahan bunyi itu terdapat dalam sebuah bahasa.

Kajian ini memanfaatkan data bahasa Rejang yang terdapat dalam buku Kamus Dwibahasa Indonesia-Rejang dan Penuntun Percakapan Bahasa Indonesia-Rejang- Inggris. Pemanfaatan data dalam dua buku tersebut dengan pertimbangan sudah mewakili pemakaian bahasa Rejang pada saat ini.

\section{HASIL DAN PEMBAHASAN}

Bahasa Rejang sebagai salah satu bahasa daerah di Provinsi Bengkulu dalam perkembangannya menyerap konsep (kata atau istilah) yang terdapat dalam bahasa lainnya, khususnya bahasa Indonesia/Melayu. Realisasi konsep yang diserap ada yang mengalami perubahan dan ada yang tidak.

\subsection{Realisasi Tetap}

Belum dapat diketahui secara lebih mendalam apa penyebab konsep tertentu dalam bahasa Indonesia tidak mengalami perubahan realisasi dalam bahasa 
Rejang. Masyarakat suku Rejang mungkin hanya mengikuti atau meniru ucapan seseorang yang diangap sebagai panutan, pertama kali memperkenalkan kata itu, atau tokoh masyarakat. Dalam beberapa potongan percakapan berikut terlihat konsep/kata tertentu yang tidak mengalami perubahan realisasi.

(1) Kakak lelaki saya akuntan.

Si akuntan.

(2) Mana bagasi saya? Ipe bagasi ku?

(3) Dimana kantor pos? Nak ipe kantor pos?

(4) Apakah Anda sudah menyelesaikan PR? Bik udem ko menea PR nu?

(5) Apakah adik perempuanmu belajar di Jakarta? Asoak nu belajean nak Jakarta?

Tampak kata akuntan, bagasi, kantor pos, PR, dan Jakarta dalam percakapan itu tidak mengalami perubahan realisasi dari bahasa Indonesia ke dalam bahasa Rejang. Kata itu terdapat dalam bidang ekonomi, pedagangan/bisnis, pendidikan, dan geografi. Kata-kata itu terkait dengan kemajuan kehidupan masyarakat. Mau tidak mau masyarakat Rejang menyerap kata itu untuk menambah konsep hidup yang belum ada agar dapat mengikuti perkembangan zaman. Contoh berikut juga memperlihatkan tidak adanya perubahan realisasi dari bahasa Indonesia ke dalam bahasa Rejang.

(6) Dia berbisnis di bidang impor dan ekspor. Si bisnis nak bidang impor ngen ekspor.

(7) Sudahkah Anda menyelesaikan pelajaran Anda? Bik udem pelajaran nu?

(8) Tante saya sedang mengobrol dengan kakek.

Bibik ku ngidong ngobrol ngen nik bong.

(9) Bisakah Anda tolong perikasa tekanan udara bannya?

Pacak ko tulung mprikso tekanan angin ban ne?

(10) Apakah reparasi ini ditanggung oleh asuransi saya?
Reparasi yo tenangung asuransi ku?

Kata bisnis, bidang, ekspor, inpor,pelajaran, ngobrol, tekanan, ban, reparasi dan asuransi dalam percakapan ada yang diserap oleh bahasa Indonesia dari bahasa asing, yaitu ekspor (export), impor (import), reparasi (reparation), dan asuransi (insurance).

\subsection{Realisasi Perubahan}

Berdasarkan data, ada tiga bentuk perubahan realisasi konsep bahasa Indonesia ke dalam bahasa Rejang, yaitu (1) realisasi penghilangan, (2) realisasi penambahan, dan (3) realisasi penggantian. Realisasi penghilangan lebih banyak ditemukan daripada dua realisasi lainnya. Sebaliknya, realisasi yang paling sedikit adalah penambahan. Perubahan dalam sebuah konsep dapat satu dan dapat pula lebih dari satu.

\subsubsection{Realisasi Satu Perubahan}

Realisasi satu perubahan yang terdapat dalam satu konsep bahasa Indonesia ke dalam bahasa Rejang dapat berupa penggantian, penambahan, dan penghilangan. Data menunjukkan penggantian lebih banyak daripada penambahan dan penghilangan. Yang berganti seperti terlihat dalam data berikut.

$$
\begin{aligned}
& \text { [a] } \rightarrow[\mathrm{o}] /-\# \\
& \text { [keluarga] } \rightarrow \text { [keluargo] } \\
& \text { [kerja] } \rightarrow \text { [kerjo] } \\
& \text { [periksa] } \rightarrow \text { [perikso] } \\
& \text { [bangsa] } \rightarrow \text { [bangso] } \\
& \text { [angkasa] } \rightarrow \text { [angkaso] } \\
& \text { [serba] } \rightarrow \text { [serbo] } \\
& \text { [terima] } \rightarrow \text { [terimo] } \\
& \text { [angsa] } \rightarrow \text { [angso] } \\
& \text { [asa] } \rightarrow \text { [aso] } \\
& \text { [baca] } \rightarrow \text { baco] } \\
& \text { [bara] } \rightarrow \text { baro] } \\
& \text { [bahaya] } \rightarrow \text { [bahayo] } \\
& \text { [bencana] } \rightarrow \text { [bencano] } \\
& \text { [benda] } \rightarrow \text { [bendo] } \\
& \text { [baja] } \rightarrow \text { [bajo] }
\end{aligned}
$$


Vokal [a] menjadi [o] pada posisi akhir berian baik yang bersuku dua atau lebih. Konsonan pada suku akhir berian itu adalah $[\mathrm{g}],[\mathrm{j}],[\mathrm{s}],[\mathrm{b}],[\mathrm{m}],[\mathrm{c}]$, $[\mathrm{r}],[\mathrm{y}],[\mathrm{n}]$, dan $[\mathrm{d}]$. Tidak ada penggantian [a] menjadi [o] dalam posisi lain awal (\#-), posisi antara konsonan dan konsonan, posisi antara vokal dan konsonan, posisi anata vokal dan vokal, dan konsonan dan vokal. Perubahan seperti itu seperti dalam bahasa Minangkabau, misalnya berapa $\rightarrow$ borapo, dimana $\rightarrow$ dimano, bila $\rightarrow$ bilo, dan lama $\rightarrow$ lamo.

Vokal [a] dapat berganti menjadi [ ] pada posisi antara konsonan dan konsonan suku kata kedua. Konsonan yang mengapit [a] adalah [1] dan [n], [c] dan [t], [t] dan [t], [y] dan [m], [n] dan [m], [1] dan $[\mathrm{s}],[\mathrm{s}]$ dan $[\mathrm{m}],[\mathrm{t}]$ dan $[\mathrm{p}],[1]$ dan $[\mathrm{t}],[\mathrm{m}]$ dan $[\mathrm{s}]$, [d] dan [p], dan [s] dan [n]. Sangat bervariasi konsonan yang mengapit vokal [a] yang menjadi vocal [ ] tersebut. Umumnya konsonannya berbeda. Data berikut memperlihatkan bahwa pada suku kata kedua tertutup vokal [a] berganti menjadi [ ]. Perubahan itu tidak hanya terjadi pada lingkungan konsonan yang berbeda, tetapi juga pada lingkunagan konsonan yang sama, yaitu antara $[\mathrm{t}]$ dan [t] pada kata catat dan ketat.

$$
\begin{aligned}
& {[\mathrm{a}] \rightarrow\left[\mathrm{J} \mathrm{K}_{[\mathrm{l}]} \mathrm{K}_{[\mathrm{n}]}\right.} \\
& \text { bulan } \rightarrow \text { bul } n \\
& \text { [a] } \rightarrow\left[\mathrm{K}_{[\mathrm{cc}}-\mathrm{K}_{[\mathrm{t}]}\right. \\
& \text { cat } \rightarrow c t \\
& \text { cacat } \rightarrow \text { cac } t \\
& {[\mathrm{a}] \rightarrow\left[\mathrm{K}_{[\mathrm{t}]} \mathrm{K}_{[\mathrm{t}]}\right.} \\
& \text { catat } \rightarrow \text { cat } t \\
& \text { ketat } \rightarrow \text { ket } t \\
& \text { [a] } \rightarrow\left[\mathrm{K}_{[\mathrm{y}]}-\mathrm{K}_{[\mathrm{m}]}\right. \\
& \text { bayam } \rightarrow \text { bay } m \\
& {[\mathrm{a}] \rightarrow\left[\mathrm{K}_{[\mathrm{n}]}-\mathrm{K}_{[\mathrm{m}]}\right.} \\
& \text { benam } \rightarrow \text { ben } m \\
& \text { [a] } \rightarrow\left[\text { ] } \mathrm{K}_{[\mathrm{l}]}-\mathrm{K}_{[\mathrm{s}]}\right. \\
& \text { balas } \rightarrow \text { bal s }
\end{aligned}
$$

$$
\begin{aligned}
& {[\mathrm{a}] \rightarrow\left[\mathrm{K}_{[\mathrm{s}]}-\mathrm{K}_{[\mathrm{m}]}\right.} \\
& \text { asam } \rightarrow \text { as } m \\
& {[\mathrm{a}] \rightarrow[] \mathrm{K}_{[\mathrm{t}]}-\mathrm{K}_{[\mathrm{p}]}} \\
& \text { atap } \rightarrow \text { at } p \\
& {[\mathrm{a}] \rightarrow[] \mathrm{K}_{[\mathrm{l}}-\mathrm{K}_{[\mathrm{t}]}} \\
& \text { bulat } \rightarrow \text { bul } t \\
& {[\mathrm{a}] \rightarrow\left[\mathrm{K}_{[\mathrm{p}]}-\mathrm{K}_{[\mathrm{t}]}\right.} \\
& \text { dapat } \rightarrow \text { dap } t \\
& {[\mathrm{a}] \rightarrow[] \mathrm{K}_{[\mathrm{m}]}-\mathrm{K}_{[\mathrm{s}]}} \\
& \text { cemas } \rightarrow \text { cem } s \\
& {[\mathrm{a}] \rightarrow\left[\mathrm{K}_{[\mathrm{d}]}-\mathrm{K}_{[\mathrm{p}]}\right.} \\
& \text { adap } \rightarrow \text { ad } p \\
& {[\mathrm{a}] \rightarrow\left[\mathrm{K}_{[\mathrm{s}]}-\mathrm{K}_{[\mathrm{n}]}\right.} \\
& \text { pesan } \rightarrow \text { pes } n
\end{aligned}
$$

Pada kata tertentu terdapat pula perubahan vokal yang berupa penambahan bunyi pada posisi akhir (/\#) seperti terlihat dalam data berikut.

$$
\begin{array}{ll}
{[\mathrm{]}] \rightarrow[\mathrm{e}]-\#} & \\
{[\text { ani-ani] }} & \rightarrow \text { [anei-anei] } \\
{[\text { besi] }} & \rightarrow \text { [besei] } \\
\text { [peti] } & \rightarrow \text { [petei] } \\
{[\text { abdi] }} & \rightarrow \text { [abdei] } \\
{[\text { aji] }} & \rightarrow \text { [ajei] } \\
{[\text { bumi] }} & \rightarrow \text { [bumei] }
\end{array}
$$

Bunyi [e] muncul karena mengikuti bunyi yang sudah ada seperti terlihat dalam penggalan perckapan berikut.

\section{Saya pikir tidak ada lagi. Asei ne cigei}

Makanan apa yang Anda makan setiap hari? Jano nтuk nu tiep bilei?

Sepertinya agak kebesaran.

Ules ne agak lei.

Tidak hanya vokal [e] yang bertambah dalam sebuah segmen bunyi, tetapi juga vokal lain, yaitu [a] seperti terlihat dalam data berikut. 


$$
\begin{aligned}
& {\left[\mathrm{]} \rightarrow[\mathrm{a}] \mathrm{K}_{[\mathrm{b}]}-\mathrm{V}_{[\mathrm{u}]}\right.} \\
& \text { abu } \rightarrow \text { abau } \\
& {[\mathrm{]}][\mathrm{a}] \mathrm{K}_{[\mathrm{d}]}-\mathrm{V}_{[\mathrm{u}]}} \\
& \mathrm{adu} \rightarrow \text { adau } \\
& {\left[\text { ] } \rightarrow[\mathrm{a}] \mathrm{K}_{[\mathrm{j}]}-\mathrm{V}_{[\mathrm{u}]}\right.} \\
& \text { baju } \rightarrow \text { bajau } \\
& {\left[\text { ] } \rightarrow[\mathrm{a}] \mathrm{K}_{[\mathrm{l}]}-\mathrm{V}_{[\mathrm{u}]}\right.} \\
& \text { bulu } \rightarrow \text { balau } \\
& {\left[\text { ] } \rightarrow[\mathrm{a}] \mathrm{K}_{[\mathrm{t}]}-\mathrm{V}_{[\mathrm{u}]}\right.} \\
& \text { batu } \rightarrow \text { butau }
\end{aligned}
$$

Penambahan [a] selalu terdapat pada suku kata akhir yang bervokal akhir $[\mathrm{u}]$ dan berkonsonan $[\mathrm{b}]$, [d], [j], [1], dan [t].

Selain terjadi perubahan vokal, juga terjadi perubahan pada konsonan. Berdasarkan data, hanya satu perubahan dalam kategori konsonan, yaitu berupa penghilangan. Ditemukan lima konsonan yang hilang, yaitu $[\mathrm{r}],[\mathrm{n}],[\mathrm{m}],[\mathrm{n}]$,dan $[\mathrm{h}]$. Penghilangan $[\mathrm{r}]$ terdapat dalam tiga posisi, yaitu pada posisi awal (\#-), posisi antara vokal dan vokal $(\mathrm{V}-\mathrm{V})$, dan posisi antara vokal dan konsonan $(\mathrm{K}-\mathrm{K})$, sedangkan penghilangan $[\mathrm{n}]$ dan $[\mathrm{h}]$ hanya dalam satu posisi. Penghilangan [r] pada posisi antara vokal dan vokal lebih banyak daripada dua posisi lainnya.

$$
\begin{aligned}
& {[\mathrm{r}] \rightarrow[\mathrm{g} / \#-} \\
& \text { [rusak] } \rightarrow \text { [usak] } \\
& \text { [racun] } \rightarrow \text { [acun] } \\
& {[\mathrm{r}] \rightarrow\left[\mathrm{]} / \mathrm{V}_{[\mathrm{u}]}-\mathrm{V}_{\text {[a] }}\right.} \\
& \text { [kurang] } \rightarrow \text { [kuang] } \\
& {[\mathrm{r}] \rightarrow\left[\mathrm{]} / \mathrm{V}_{[\mathrm{a}]}-\mathrm{V}_{\text {[a] }}\right.} \\
& \text { [arang] } \rightarrow \text { [aang] } \\
& {[\mathrm{r}] \rightarrow\left[\mathrm{]} / \mathrm{V}_{[\mathrm{u}}-\mathrm{V}_{\text {[u] }}\right.} \\
& \text { [buruk] } \rightarrow \text { [buuk] } \\
& {[\mathrm{r}] \rightarrow\left[\mathrm{]} / \mathrm{V}_{[\mathrm{a}]}-\mathrm{V}_{[\mathrm{i}]}\right.} \\
& \text { [baris] } \rightarrow \text { [bais] } \\
& {[\mathrm{r}] \rightarrow\left[\mathrm{]} / \mathrm{V}_{[\mathrm{e}]}-\mathrm{V}_{\text {[a] }}\right.} \\
& \text { [deras] } \rightarrow \text { [dees] }
\end{aligned}
$$

$$
\begin{aligned}
& {[\mathrm{r}] \rightarrow\left[\mathrm{]} / \mathrm{V}_{[\mathrm{e}]}-\mathrm{V}_{\text {[e] }}\right.} \\
& \text { [beres] } \rightarrow \text { [beres] } \\
& {[\mathrm{r}] \rightarrow\left[\mathrm{]} / \mathrm{V}_{[\mathrm{e}]}-\mathrm{K}_{[\mathrm{n}]}\right.} \\
& \text { [bernas] } \rightarrow \text { [benas] } \\
& {[\mathrm{r}] \rightarrow\left[\mathrm{]} / \mathrm{V}_{[\mathrm{e}]} \mathrm{K}_{[\mathrm{t}]}\right.} \\
& \text { [gertak] } \rightarrow \text { [getak] } \\
& {[\mathrm{r}] \rightarrow\left[\mathrm{]} / \mathrm{V}_{[\mathrm{e}]} \mathrm{K}_{[\mathrm{b}]}\right.} \\
& \text { [kerbau] } \rightarrow[\text { kebau] }
\end{aligned}
$$

Vokal yang mengapit [r] pada posisi V-V adalah [u]-[a], [a]-[a], [u]-[u], [a]-[i], [e]-[a], dan [e]-[e]. Ada dua vokal yang sama yang mengapit [r] tersebut, yaitu $[\mathrm{u}]-[\mathrm{u}]$ dan $[\mathrm{e}]-[\mathrm{e}] \mathrm{d}$. Vokal pada posisi V-K hanya ada satu, yaitu [e], dengan konsonan yang berbeda, yaitu [n], [t], dan [b].

Penghilangan konsonan $[\mathrm{n}],[\mathrm{m}]$,dan $[\mathrm{n}]$ terdapat pada suku kata pertama pada pisisi antara vokal dan konsonan (V-K). Vokal penghilangan [n] adalah [e], $[\mathrm{u}]$, dan [a] sedangkan konsonannya [k] saja. Vokal dan konsonan penghilangan [m] adalah [a] dan [p], dan vocal dan konsonan penghilangan [n] adalah [e] dan $[\mathrm{c}] ;[\mathrm{u}]$ dan $[\mathrm{c}]$.

$$
\begin{aligned}
& {[\mathrm{n}] \rightarrow\left[\mathrm{]} / \mathrm{V}_{[\mathrm{e}]}-\mathrm{K}_{[\mathrm{k}]}\right.} \\
& \text { [bengkel] } \rightarrow \text { [bekel] } \\
& {[\mathrm{p}] \rightarrow\left[\mathrm{]} / \mathrm{V}_{[\mathrm{u}]}-\mathrm{K}_{[\mathrm{k}]}\right.} \\
& \text { [bungkuk] } \rightarrow \text { [bukuk] } \\
& \text { [bungkus] } \rightarrow \text { [bukus] } \\
& {[\mathrm{p}] \rightarrow\left[\mathrm{]} / \mathrm{V}_{[\mathrm{a}]} \mathrm{K}_{[\mathrm{k}]}\right.} \\
& \text { [cangkok] } \rightarrow \text { [cakok] } \\
& \text { [dangkal] } \rightarrow \text { [daka] } \\
& \text { [angka] } \rightarrow \text { [ako] } \\
& \text { [angkut] } \rightarrow \text { [akut] } \\
& \text { [bangkit] } \rightarrow \text { [bakit] } \\
& {[\mathrm{m}] \rightarrow\left[\mathrm{]} / \mathrm{V}_{[\mathrm{a}]}-\mathrm{K}_{[\mathrm{p}]}\right.} \\
& \text { [lampu] } \rightarrow \text { [lapu] } \\
& \text { [sampai] } \rightarrow \text { [sapei] } \\
& \text { [dampar] } \rightarrow \text { [dapar] } \\
& \text { [dampak] } \rightarrow \text { [dapak] } \\
& {[\mathrm{n}] \rightarrow\left[\mathrm{]} / \mathrm{V}_{[\mathrm{e}]}-\mathrm{K}_{[\mathrm{c}]}\right.}
\end{aligned}
$$




$$
\begin{aligned}
& \text { [encer] } \\
& {[\mathrm{n}] \rightarrow[\text { [ecer }]} \\
& {\left[\text { buncit } \quad \mathrm{V}_{[\mathrm{u}]}-\mathrm{K}_{[\mathrm{cc}]}\right.} \\
& \rightarrow \text { [bucit }]
\end{aligned}
$$

Penghilangan konsonan $[\mathrm{h}]$ hanya terdapat awal kata. Penghilangan $[\mathrm{h}]$ pada posisi awal itu terjadi karena [h] dianggap tidak berbunyi. Ketika diucapkan, [hidup] dan [idup] terasa tidak berbeda.

$$
\begin{aligned}
& {[\mathrm{h}] \rightarrow[\mathrm{]} / \#-} \\
& \text { [hidup] } \rightarrow \text { [idup] } \\
& \text { [hadis] } \rightarrow \text { [adis] } \\
& \text { [hajat] } \rightarrow \text { [ajat] } \\
& \text { [haji] } \rightarrow \text { [ajai] } \\
& \text { [hadap] } \rightarrow \text { [adap] } \\
& \text { [handuk] } \rightarrow \text { [anduk] } \\
& \text { [hirup] } \rightarrow \text { [irup] } \\
& \text { [hukum] } \rightarrow \text { [ukum] }
\end{aligned}
$$

\subsubsection{Realisasi Dua Perubahan}

Dalam sebuah konsep realisasi dua perubahan dapat berupa penghilangan dan penambahan dan penghilangan dan penggantian Yang dihilangkan adalah konsonan [r] pada posisi awal dan pada posisi antara vokal dan vokal, [h] pada posisi awal, dan [n] pada posisi antara vokal [a] dan konsonan [t], dan [n] pada posisi antara vokal [e] dan konsonan [k]. Selanjutnya, yang ditambah adalah vokal [i] dalam [ajai] pada posisi \#- dan [a] dalam [agai] dan [batau] dan [ ] dalam [dek i] pada posisi antara konsonan dan vokal. Yang diganti adalah [f] menjadi [p] pada posisi antara vokal dan cokal , [a] menjadi [e], [a] menjadi [ ] dan [a] menjadi [o] pada posisi akhir seperti terlihat dalam data berikut.

$$
\begin{aligned}
& {[\mathrm{r}] \rightarrow[\mathrm{]} / \#-\text { dan }[\mathrm{]} \rightarrow[\mathrm{i}] / \mathrm{H}} \\
& \text { [raja] } \rightarrow \text { [ajai] } \\
& {[\mathrm{r}] \rightarrow[\mathrm{]} / \mathrm{H}-\mathrm{dan}[\mathrm{]} \rightarrow[\mathrm{a}] / \#-} \\
& \text { [ragi] } \rightarrow \text { [agai] } \\
& {[\mathrm{r}] \rightarrow\left[\mathrm{]} / \mathrm{V}_{[\mathrm{a}]^{-}} \mathrm{V}_{[\mathrm{a}]} ;[\mathrm{a}] \rightarrow[\mathrm{e}] / \mathrm{K}_{[\mathrm{r}]}-\mathrm{K}_{[\mathrm{t}]}\right.} \\
& \text { [darat] } \rightarrow \text { [daet] } \\
& {[\mathrm{r}] \rightarrow\left[\mathrm{]} / \mathrm{V}_{[\mathrm{e}]}-\mathrm{V}_{[\mathrm{a}]} ;[\mathrm{a}] \rightarrow[\mathrm{e}] / \mathrm{K}_{[\mathrm{r}]}-\mathrm{K}_{[\mathrm{s}]}\right.}
\end{aligned}
$$

$$
\begin{aligned}
& \text { [deras } \rightarrow \text { [dees] }
\end{aligned}
$$

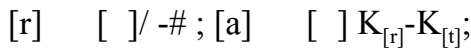

$$
\begin{aligned}
& \text { surat } \rightarrow \text { su } t \\
& {[\mathrm{r}] \rightarrow\left[\mathrm{]} / \mathrm{V}_{[\mathrm{a}]}-\mathrm{V}_{\text {[a] }} ;[\mathrm{a}] \rightarrow[\mathrm{o}] /-\#\right.} \\
& \text { [cara] } \rightarrow \text { [cao] } \\
& {[\mathrm{r}] \rightarrow[\mathrm{]} / \#-;[\mathrm{a}] \rightarrow[\mathrm{o}] /-\#} \\
& \text { [rusa] } \rightarrow \text { [uso] } \\
& {[\mathrm{n}] \rightarrow\left[\mathrm{V}_{[\mathrm{a}]^{-}} \mathrm{K}_{[\mathrm{t}]} ;[\mathrm{]}] \rightarrow[\mathrm{a}] \mathrm{K}_{[\mathrm{t}]^{-}}-\mathrm{V}_{[\mathrm{u}]}\right.} \\
& \text { bantu } \rightarrow \text { batau } \\
& {[\mathrm{g}] \rightarrow\left[\mathrm{V}_{[\mathrm{a}]}-\mathrm{K}_{[\mathrm{k}]} ;[\mathrm{]}] \rightarrow\left[\mathrm{K}_{[\mathrm{k}]}-\mathrm{V}_{[\mathrm{i}]}\right.\right.} \\
& \text { dengki } \rightarrow \text { dek } i \\
& {[\mathrm{~h}] \rightarrow\left[\mathrm{g} / \#-\text { dan }[\mathrm{f}] \rightarrow[\mathrm{p}] / \mathrm{V}_{[\mathrm{a}]^{-}} \mathrm{V}_{[\mathrm{a}]}\right.} \\
& \text { hafal } \rightarrow \text { apal }
\end{aligned}
$$

Data dua perubahan berikut dapat dikelompokkan juga terbagi dua, yaitu (1) penggantian dan penghilangan dan (2) pengantian dan pengantian. Pada kelompok pertama yang diganti dan yang dihilangkan adalah vokal [i] menjai [ea], [a] menjadi [ea], dan [u] menjadi [oa] pada posisi antara konsonan dan konsonan, dan yang dihilangkan konsonan [1] pada posisi akhir.

$$
\begin{aligned}
& {[\mathrm{i}] \rightarrow[\mathrm{ea}] / \mathrm{K}_{[\mathrm{d}]}-\mathrm{K}_{[\mathrm{ll}} \text { dan [1] } \rightarrow[\mathrm{]} / \mathrm{\#}} \\
& \text { adil } \rightarrow \text { adea } \\
& {[\mathrm{i}] \rightarrow[\mathrm{ea}] / \mathrm{K}_{[\mathrm{dd}]}-\mathrm{K}_{[1]}-\text { dan [1] } \rightarrow[\mathrm{]} / / \mathrm{\#}} \\
& \text { andil } \rightarrow \text { andea } \\
& {[\mathrm{a}] \rightarrow[\mathrm{ea}] / \mathrm{K}_{[\mathrm{k}]}-\mathrm{K}_{[\mathrm{[l]}} \text { dan [1] } \rightarrow[\mathrm{]} / \mathrm{- \#}} \\
& \text { akal } \rightarrow \text { akea } \\
& {[\mathrm{a}] \rightarrow[\mathrm{ea}] / \mathrm{K}_{[\mathrm{m}]}-\mathrm{K}_{[\mathrm{l}]} \text { dan [1] } \rightarrow[\mathrm{]}]-/-\#} \\
& \text { amal } \rightarrow \text { amea } \\
& {[\mathrm{u}] \rightarrow[\mathrm{oa}] / \mathrm{K}_{[\mathrm{t}]}-\mathrm{K}_{[\mathrm{l}]} \text { dan [l] } \rightarrow[\mathrm{]}] / \#} \\
& \text { betul } \rightarrow \text { betoa }
\end{aligned}
$$

Pada kelompok kedua, penggantian pertama adalah vokal [o] menjadi [e], [a] menjadi [ ], [u] menjadi [o], dan [u] menjadi [oa] pada posisi antara konsonan dan konsonan. Pada penggantian kedua tidak hanya vokal yang berganti, tetapi juga 
konsonan. Vokal yang diganti adalah vocal [i] menjadi [ ] dan konsonan [h] menjadi [k].

$$
\begin{aligned}
& {[\mathrm{o}] \rightarrow[\mathrm{e}] / \mathrm{K}_{[\mathrm{k}]}-\mathrm{K}_{[\mathrm{p}]} ;[\mathrm{h}] \rightarrow[\mathrm{k}] / \text {-\# }} \\
& \text { kopiah } \rightarrow \text { kepiak } \\
& {[\mathrm{a}] \rightarrow[] \mathrm{K}_{[\mathrm{k}]}-\mathrm{K}_{[\mathrm{m}]} ;[\mathrm{i}] \rightarrow[\mathrm{]} / \text {-\# }} \\
& \mathrm{kami} \rightarrow \text { k m } \\
& {[\mathrm{u}] \rightarrow[\mathrm{o}] / \mathrm{K}_{[\mathrm{p}]}-\mathrm{K}_{[\mathrm{[}]} ;[\mathrm{h}] \rightarrow[\mathrm{k}] / \text {-\# }} \\
& \text { puluah } \rightarrow \text { poloak } \\
& {[\mathrm{u}] \rightarrow[\text { oa }] / \mathrm{K}_{[\mathrm{n}]}-\mathrm{K}_{[\mathrm{h}]} \text { dan }[\mathrm{h}] \rightarrow[k] /-\#} \\
& \text { penuh } \rightarrow \text { penoak }
\end{aligned}
$$

Data dua perubahan berikut berupa penambahan dan penggantian. Yang ditambah adalah vokal [e] pada posisi antara konsonan [1] dan vokal [i], vokal [e] pada posisi antara konsonan [k] dan vokal [a], vokal [a] pada posisi antara [u] dan konsonan [h], vokal [a] pada posisi antara [i] dan konsonan [h], vokal [a] pada posisi antara [o] dan konsonan [h], vokal [a] pada posisi antara [e] dan konsonan [h]. Yang diganti adalah $[\mathrm{h}]$ menjadi $[\mathrm{k}]$ pada posisi akhir.

$$
\begin{aligned}
& {\left[\mathrm{]} \rightarrow[e] / \mathrm{K}_{[1]}-\mathrm{V}_{[\mathrm{e}]} ;[\mathrm{h}] \rightarrow[k] /\right. \text { \# }} \\
& \text { [bilah } \rightarrow \text { [bileak] } \\
& {\left[\mathrm{]} \rightarrow[e] / \mathrm{K}_{[\mathrm{k}]}-\mathrm{V}_{[\mathrm{a}]} ;[\mathrm{h}] \rightarrow[k] /-\#\right.} \\
& \text { [berkah] } \rightarrow \text { [berkeak] } \\
& \text { [buluh] } \rightarrow \text { [boloak] } \\
& \text { [cegah] } \rightarrow \text { [cegeak] } \\
& \text { [curah] } \rightarrow \text { [cueak] } \\
& \text { [berkah] } \rightarrow \text { [berkeak] }
\end{aligned}
$$$$
\left[\mathrm{]} \rightarrow[\mathrm{a}] / \mathrm{V}_{[\mathrm{u}]}-\mathrm{K}_{[\mathrm{h}]} ;[\mathrm{h}] \rightarrow[\mathrm{k}] /-\#\right.
$$$$
\text { [kumuh } \rightarrow \text { [kumuak] }
$$$$
\left[\mathrm{]} \rightarrow[\mathrm{a}] / \mathrm{V}_{[\mathrm{i}]}-\mathrm{K}_{[\mathrm{h}]} ;[\mathrm{h}] \rightarrow[\mathrm{k}] /\right. \text {-\# }
$$$$
\text { [lebih } \rightarrow \text { [lebiak] }
$$$$
\left[\mathrm{]} \rightarrow[\mathrm{a}] / \mathrm{V}_{[\mathrm{o}]}-\mathrm{K}_{[\mathrm{h}]} ;[\mathrm{h}] \rightarrow[\mathrm{k}] /\right. \text {-\# }
$$$$
\text { [lemah] } \rightarrow \text { [lemoak] }
$$$$
\left[\mathrm{]} \rightarrow[\mathrm{a}] / \mathrm{V}_{[\mathrm{e}]}-\mathrm{K}_{[\mathrm{h}]} ; \mathrm{h}\right] \rightarrow[\mathrm{k}] / \text {-\# }
$$$$
\text { [leleh] } \rightarrow \text { [leleak] }
$$$$
\left.\left[\mathrm{]} \rightarrow[\mathrm{e}] / \mathrm{K}_{[\mathrm{d}]}\right]_{[\mathrm{ad}]} ; \mathrm{h}\right] \rightarrow[\mathrm{k}] / \text {-\# }
$$

$$
\begin{aligned}
& \text { [lidah] } \rightarrow \text { [lideak] } \\
& {\left[\mathrm{]} \rightarrow[\mathrm{e}] / \mathrm{K}_{[\mathrm{r}]}-\mathrm{V}_{[\mathrm{a}]} ;[\mathrm{h}] \rightarrow[\mathrm{k}] /-\#\right.} \\
& \text { [marah] } \rightarrow \text { [mareak] } \\
& {\left[\mathrm{]} \rightarrow[\mathrm{e}] / \mathrm{K}_{[\mathrm{d}]}-\mathrm{V}_{[\mathrm{a}]} ;[\mathrm{h}] \rightarrow[\mathrm{k}] / \#\right.} \\
& \text { [mudah] } \rightarrow \text { [mudeak] } \\
& {\left[\mathrm{]} \rightarrow[\mathrm{e}] / \mathrm{K}_{[\mathrm{r}]}-\mathrm{V}_{[\mathrm{a}]} ;[\mathrm{h}] \rightarrow[\mathrm{k}] /-\#\right.} \\
& \text { [nanah] } \rightarrow \text { [naneak] } \\
& {\left[\mathrm{]} \rightarrow[\mathrm{e}] / \mathrm{K}_{[\mathrm{p}]}-\mathrm{V}_{[\mathrm{a}]} ;[\mathrm{h}] \rightarrow[\mathrm{k}] /-\#\right.} \\
& \text { [papah] } \rightarrow \text { [papeak] }
\end{aligned}
$$

\subsubsection{Realisasi Tiga Perubahan}

Berdasarkan data, ada tiga bentuk perubahan yang terjadi dalam sebuah konsep bahasa Indonesia ke dalam bahasa Rejang, yaitu (1) penghilangan, penggantian, dan penambahan, (2) penggantian, penggantian, dan penggantian, dan (3) penggantian, penggantian, dan penambahan. Bentuk perubahan (1) seperti terlihat dalam data berikut.

$$
\begin{aligned}
& {[\mathrm{r}] \rightarrow[]^{2} / \mathrm{V}_{[\mathrm{u}]}-\mathrm{V}_{[\mathrm{a}]} \quad ; \quad[\mathrm{h}] \rightarrow[\mathrm{k}] /-\# \quad ;} \\
& {\left[\mathrm{]} \rightarrow[\mathrm{e}] / \mathrm{K}_{[\mathrm{r}]}-\mathrm{V}_{\text {[a] }}\right.} \\
& \text { [curah] } \rightarrow \text { [cueak] } \\
& {[\mathrm{r}] \rightarrow\left[\mathrm{]} / \mathrm{V}_{[\mathrm{u}]^{-}} \mathrm{V}_{[\mathrm{a}]} ;[\mathrm{h}] \rightarrow[\mathrm{k}] /-\# ;[\mathrm{]} \rightarrow[\mathrm{e}] /\right.} \\
& \mathrm{K}-\mathrm{K} ;[\mathrm{r}-[\mathrm{h}] \\
& \text { [murah] } \rightarrow[\text { mueak }] \\
& {[\mathrm{r}] \rightarrow\left[\mathrm{]} / \mathrm{V}_{[\mathrm{u}]}-\mathrm{V}_{[\mathrm{u}]} ;[\mathrm{h}] \rightarrow[\mathrm{k}] / \# ;[\mathrm{]}] \rightarrow[\mathrm{a}] /\right.} \\
& \mathrm{V}_{[\mathrm{u}]}-\mathrm{K}_{[\mathrm{h}]} \\
& \text { [guruh] } \rightarrow \text { [guuak] } \\
& \text { [n] } \rightarrow\left[\text { ] } / \mathrm{V}_{[\mathrm{oo}]}-\mathrm{K}_{[\mathrm{kk}} ;[\mathrm{h}] \rightarrow[\mathrm{k}] /-\# ; \quad[\mathrm{]} \rightarrow[\right. \\
& \mathrm{e}] / \mathrm{K}_{[\mathrm{k}]}-\mathrm{V}_{\text {[a] }} \\
& \text { [langkah] } \rightarrow \text { [lakeak] }
\end{aligned}
$$

Yang dihilangkan adalah konsonan $[\mathrm{r}]$ pada posisi antara vokal $[\mathrm{u}]$ dan vokal [a] dan pada posisi antara vokal $[\mathrm{u}]$ dan $[\mathrm{u}]$. Yang diganti adalah konsonan [h] menjadi [k] pada posisi akhir. Selanjutnya, yang ditambah adalah vokal [e] pada posisi antara konsonan [r] dan konsonan [h], vokal [e] pada posisi antara konsonan [k], dan vokal [a] pada posisi antara vocal $[\mathrm{u}]$ dan konsonan $[\mathrm{h}]$. 
Satu relasiasi konsep berikut memperlihatkan tiga perubahan yang sama, yaitu penggantian, penggantian, dan penggantian. Yang diganti adalah konsonan [h] menjadi [k] pada posisi akhir, vokal [o] menjadi [u] pada posisi antara konsonan [b] dan konsonan [1], vokal [e] menjadi [ea] pada posisi antara konsonan [1] dan konsonan [k].

$$
\begin{aligned}
& {[\mathrm{h}] \rightarrow[\mathrm{k}] / \text {-\# dan }[\mathrm{o}] \rightarrow[\mathrm{u}] / \mathrm{K}_{[\mathrm{b}]}-\mathrm{K}_{[1]} ;[\mathrm{e}]} \\
& \rightarrow[\mathrm{ia}] / \mathrm{K}_{[1]}-\mathrm{K}_{[\mathrm{k}]} \\
& \text { boleh } \rightarrow \text { buliak }
\end{aligned}
$$

Dua relasiasi konsep berikut memperlihatkan tiga perubahan, dua penggantian satu Penambahan. Yang diganti adalah konsonan $[\mathrm{h}]$ menjadi [k] pada posisi akhir, penggantian[r] menjadi [1] pada posisi antara vokal [a] dan vokal [a], penggantian [f] menjadi [p] pada poisisi antara vokal [a] dan konsonan [k], penambahan vokal [e] pada posisi antara konsonan [r] dan vokal [a], penambahan vokal [e] pada posisi antara konsonan [k] dan konsonan [h]

$$
\begin{aligned}
& {[\mathrm{h}] \rightarrow[\mathrm{k}] /-\# ;[\mathrm{r}] \rightarrow[1] / \mathrm{V}_{[\mathrm{a}]}-\mathrm{V}_{[\mathrm{a}]} ;[\mathrm{]}][\mathrm{e}] /} \\
& \mathrm{K}_{[\mathrm{r}]}-\mathrm{V}_{[\mathrm{a}]} \\
& \text { darah } \rightarrow \text { daleak } \\
& {[\mathrm{h}] \rightarrow[\mathrm{k}] /-\# ;[\mathrm{f}] \rightarrow[\mathrm{p}] / \mathrm{V}_{[\mathrm{a}]}-\mathrm{K}_{[\mathrm{k}]} ;[\mathrm{]}] \rightarrow[} \\
& \mathrm{e}] / \mathrm{K}_{[\mathrm{k}]}-\mathrm{K}_{[\mathrm{h}]} \\
& \text { nafkah } \rightarrow \text { napkeak }
\end{aligned}
$$

\subsubsection{Realisasi Empat Perubahan}

Perubahan sebanyak empat kali dalam sebuah konsep bahasa Indonesia ke dalam bahasa Rejang dapat dikatakan sangat sedikit atau sangat jarang. Satu relasiasi konsep berikut memperlihatkan empat perubahan, yaitu penghilangan, penggantian, penggantian, dan penambahan. Yang dihilangkan adalah konsonan [ $\mathrm{\eta}]$, yang diganti konsonan [h] menjadi [k] pada posisi akhir, vokal [o] menjadi $[\mathrm{u}]$ pada posisi antara konsonan [b] dan konsonan [ $\mathrm{\eta}]$, dan penambahan vokal [e] pada posisi antara konsonan [k] dan konsonan [a].

$$
\begin{aligned}
& {[\mathrm{p}] \rightarrow\left[\mathrm{J} / \mathrm{V}_{[\mathrm{o}]}-\mathrm{K}_{[\mathrm{k}]} ;[\mathrm{h}] \rightarrow[\mathrm{k}] /-\# ;[\mathrm{o}] \rightarrow[\mathrm{u}] /\right.} \\
& \mathrm{K}_{[\mathrm{b}]}-\mathrm{K}_{[\mathrm{b}]} ;[\mathrm{[}] \rightarrow[\mathrm{e}] / \mathrm{K}_{[\mathrm{k}]}-\mathrm{V}_{[\mathrm{a}]} \\
& \text { bongkah } \rightarrow \text { bukeak }
\end{aligned}
$$

\section{PENUTUP}

\subsection{Simpulan}

Bahasa Rejang adalah salah satu bahasa daerah di Pulau Sumatera yang dalam perkembangannya memerlukan konsep bahasa lain, khususnya konsep bahasa Indonesia dan Melayu Bengkulu. Realisasi konsep yang diserap ada yang secara utuh dan ada yang mengalami perubahan.

Berdasarkan data, realisasi kata bahasa Indonesia yang mengalami perubahan dalam bahasa Rejang disebabkan oleh penghilangan di awal, di tengah (singkope), dan di akhir (apokope), penambahan, dan penggantian bunyi (substitusi). Adanya perubahan bunyi itu tentu disebabkan oleh beberapa faktor, antar lain, kaidah bunyi bahasa Rejang, kecenderungan pengucapan penutur, kecenderungan ingin menyederhanakan, dan pengaruh ucapan bahasa Melayu Bengkulu atau bahasa lainya.

Bahasa Rejang akan mengalami perkembangan sesuai dengan kebutuhan penuturnya. Ada kemungkinan kosakata asli bahasa Rejang akan ditinggalkan penuturnya dan akan berganti dengan kosakata Rejang yang merupakan campuran dengan dengan bahasa lain.

\subsection{Saran}

Bahasa Rejang sebagai salah satu bahasa daerah di Provinsi Bengkulu perlu terus dipelihara dan dilindungi (dilestarikan) oleh penuturnya. Dalam rangka itu kajian keunikan dan hubungannya dengan bahasa lain perlu terus digali melalui penelitian yang lebih mendalam. Sampai saat ini belum ada penelitian kebahasaan yang dapat mengungkap bagaimana realisasi bunyi yang terkait dengan hubungan nenek moyang suku Rejang dengan suku lain, misalnya dengan suku Minangkabau di Sumatera Barat atau dengan sukusuku lain di Provinsi Bengkulu. 
Hidayatul Astar: Realisasi Konsep Bahasa Indonesia dalam Bahasa Rejang

\section{DAFTAR PUSTAKA}

Astar, Hidayatul, dkk. 2013. Penuntun Percakapan Indonesia-Rejang-Inggris. Yogyakarta: Azzagrafika

Crowey, Terry. 1987. An Introduction to Historical Linguistics. Port Moresby: University of Papua New Guinea Press.

Hock, Hans Hnedrich. 1986. Principles of Historical Linguistics. Berlin; New York; Amsterdam: Mouton de Gruyter

Juwono, Sudarsono. 1998. "Kebinekaan Bahasa, Pembangunan Bangsa, dan Era Globalisasi”. Jakarta: Pusat Bahasa, Departemen Pendidikan Nasional

Mahsun. 1995. Dialektologi Diakronis Sebuah Pengantar. Yoyakarta: Gajah Mada University Press.

Robins, R.H. 1989/1992. Linguistik Umum: sebuah Pengantar. Terjemahan General Linguistics oleh S. Djajanegara. Yogyaakarta: Kanisius.

Summer Institut Linguistics. 2006. Bahasa-bahasa di Indonesia (Languages of Indonesia). Jakarta: SIL Internasional Cabang Indonesia.

Tim Pemetaan Bahasa. 2008. Bahasa dan Peta Bahasa di Indonesia. Jakarta: Pusat Bahasa, Departemen Pendidikan Nasional.

Tim Penyusun. 2013. Kamus Dwibahasa Indonesia-Rejang. Yogyakarta: Azzagrafika. 
Hidayatul Astar: Realisasi Konsep Bahasa Indonesia dalam Bahasa Rejang 